\title{
Transformation of Bacillus licheniformis protoplasts by plasmid DNA
}

\author{
Zoltán Prágai, András Holczinger and Tibor Sík
}

Author for correspondence: Zoltán Prágai. Fax: +36 28 310804.e-mail : pz@rkt.gau.hu

Department of

Biotechnology, Gödöllö

University of Agricultural

Sciences, Gödöllö, Páter

K. u. 1., H-2103, Hungary

\begin{abstract}
A simple and efficient protoplast regeneration and PEG-induced transformation procedure was developed for Bacillus licheniformis. The protoplast stabilizing osmoticum was $0.5 \mathrm{M}$ sucrose in the regenerating media, and the restoration of cell wall was carried out at pH 8.4. The mean frequency of regeneration was $83 \%$. The transformation efficiency was studied with four different strains and five plasmids, and ranged from $3.5 \times 10^{5}$ to $7.2 \times 10^{6}$ transformants per $\mu \mathrm{g}$ plasmid DNA depending on the plasmid, and on the donor and recipient strains used. Endonuclease digested and ligated plasmid DNA could also be used to transform the protoplasts, but at a lower frequency.
\end{abstract}

Keywords: Bacillus licheniformis, protoplast transformation, plasmid

\section{INTRODUCTION}

Bacillus licheniformis is used for the industrial production of the peptide antibiotic bacitracin, $\alpha$-amylase, $\beta$-lactamase, alkaline protease and alkaline phosphatase (Kleinkauf \& von Döhren, 1987; Harwood, 1992). In a strain improvement and genetic manipulation programme plasmid DNA transfer is indispensable. There are several methods to introduce plasmid DNA into Bacillus species, such as transformation of competent cells, PEG-mediated transformation of protoplasts, electroporation, transduction and conjugation (Bron, 1990), but in the case of some Bacillus licheniformis strains only protoplast transformation was successful (Jensen \& Hulett, 1989; A. Holczinger, unpublished results). The method described for Bacillus subtilis by Chang \& Cohen (1979) cannot be applied to $B$. licheniformis because of deficient cell wall regeneration of the protoplasts. Regenerants could only be obtained by changing the composition of the growth and regeneration media, or the incubation temperature. Even so, the efficiency of regeneration and transformation was low and variable (Grosch \& Wollweber, 1982; Bourne \& Dancer, 1986; Jensen \& Hulett, 1989; Bron, 1990; Wati et al., 1990).

A transformation procedure is reported here for protoplasts of $B$. licheniformis strains with different plasmids. The method is a reproducible variant of the procedure of Chang \& Cohen (1979), in which the media are modified to increase regeneration and transformation frequencies.

Abbreviations: Ap, ampicillin; $\mathrm{Cm}$, chloramphenicol; $\mathrm{Km}$, kanamycin; $\mathrm{TC}$, tetracycline; $\mathrm{EtBr}$, ethidium bromide; $\mathrm{MIC}$, minimal inhibitory concentration; PEG, polyethylene glycol; RT, room temperature.

\section{METHODS}

Bacterial strains and plasmids. Strains used in the experiments are described in Table 1 and plasmids in Table 2.

Media. P-solution: $1.25 \mathrm{~g} \mathrm{NH}_{4} \mathrm{Cl}, 15 \mathrm{~g}$ Tris, $0.075 \mathrm{~g} \mathrm{NaCl}$, $0.045 \mathrm{~g} \mathrm{KCl}, 0 \cdot 375 \mathrm{~g} \mathrm{Na}_{2} \mathrm{SO}_{4} \cdot 10 \mathrm{H}_{2} \mathrm{O}, 5 \cdot 33 \mathrm{~g} \mathrm{MgCl}_{2} \cdot 6 \mathrm{H}_{2} \mathrm{O}$ and $171.15 \mathrm{~g}$ sucrose per litre, $\mathrm{pH} 8.4$ [modified hypertonic medium of Fodor et al. (1975)]. P-lys medium: P-solution containing $2 \mathrm{mg}$ lysozyme (Serva) $\mathrm{ml}^{-1}$ and then filter-sterilized. PEG solution: $60 \%$ (w/v) PEG 6000 (Serva) in P-solution. Lysozyme solution, neutral phenol/chloroform and TE buffer were according to Kieser (1984). YTA media were described by Sík et al. (1980). ART liquid medium: $5 \mathrm{~g} \mathrm{NaCl}, 5 \mathrm{~g}$ yeast extract (Oxoid L21), $5 \mathrm{~g}$ tryptone (Oxoid L42), 6.057 g Tris, $5 \mathrm{~g}$ glucose, $171 \cdot 15 \mathrm{~g}$ sucrose, $1 \mathrm{ml} 0 \cdot 5 \mathrm{M} \mathrm{CaCl}_{2}, 1 \mathrm{ml} \cdot 0 \mathrm{M} \mathrm{MgSO}_{4}$, $1 \mathrm{ml} 0.5 \mathrm{M} \mathrm{MnSO}_{4}$ per litre, $\mathrm{pH} \mathrm{8.4.} \mathrm{AR'T} \mathrm{soft-agar} \mathrm{and} \mathrm{ART}$ agar media consisted of AR'T liquid medium containing $0.8 \%$ (w/v) or $1.8 \%(\mathrm{w} / \mathrm{v}$ ) agar (Oxoid L11), respectively.

DNA isolation. Plasmid DNA was isolated from B. subtilis 27 and $B$. licheniformis 19 by a large-scale plasmid purification method using alkaline lysis and $\mathrm{CsCl}-\mathrm{EtBr}$ centrifugation (Bron, 1990). Plasmid DNA content of B. licheniformis transformants was examined by a quick-test method. From selective Y'TA agar medium one loopful of bacteria was suspended in $50 \mu \mathrm{l}$ lysozyme solution and incubated for $20 \mathrm{~min}$ at $37^{\circ} \mathrm{C}$. Then $25 \mu \mathrm{l}$ $2 \%$ SDS solution was added and the mixture was extracted with $25 \mu \mathrm{l}$ neutral phenol/chloroform. After centrifugation (RT, $5 \mathrm{~min}, 6000 \mathrm{~g}$ ), DNA and RNA structures in the supernatant were separated by $0.7 \%$ agarose gel electrophoresis.

Preparation of protoplasts. Bacteria were grown in YTA broth overnight $(14-16 \mathrm{~h})$ at $37^{\circ} \mathrm{C}$. The cultures were subsequently diluted 100-fold into $5 \mathrm{ml}$ fresh YTA medium and grown for $1.5-2 \mathrm{~h}$ at $37^{\circ} \mathrm{C}$ (the number of c.f.u. was around $3-6 \times$ $10^{7} \mathrm{ml}^{-1}$ ). The cells were centrifuged at RT for $5 \mathrm{~min}$ at $6000 \mathrm{~g}$ and resuspended in the same volume of P-lys medium. After $90 \mathrm{~min}$ at $37^{\circ} \mathrm{C}$ (without shaking), almost $100 \%$ of the cells 
Table 1. Strains

\begin{tabular}{|lll|}
\hline \multicolumn{1}{|c|}{ Strain } & Product & \multicolumn{1}{c|}{ Source } \\
\hline B. licheniformis & & \\
ATCC 9800 & - & OKI, Budapest, Hungary \\
ATCC 10716 UM12 & Bacitracin & T. Imanaka, Osaka University, Osaka, Japan \\
19 & Bacitracin & Our laboratory \\
$16^{*}$ & Bacitracin & Our laboratory \\
B. subtilis 27 & pUB110 donor & T. Imanaka, Osaka University, Osaka, Japan \\
\hline
\end{tabular}

* A derivative of $B$. licheniformis 19 cured of phage BLF.

Table 2. Plasmids

\begin{tabular}{|lcccl|}
\hline Plasmid & $\begin{array}{c}\text { Antibiotic resistance } \\
\text { conferred in Bacillus }\end{array}$ & $\begin{array}{c}\text { Size } \\
\mathbf{( k b )}\end{array}$ & $\begin{array}{c}\text { Copy number } \\
\text { (per chromosome) }\end{array}$ & Reference \\
\hline pUB110 & $\mathrm{Km}$ & $4 \cdot 548$ & 50 & Sueoka et al. (1986) \\
pUBUC18* & $\mathrm{Km}$ & $7 \cdot 234$ & 50 & Our laboratory \\
pAT187 & $\mathrm{Km}$ & $10 \cdot 5$ & 15 & Trieu-Cuot et al. $(1987)$ \\
pHV33 & $\mathrm{Cm}$ & $7 \cdot 278$ & 10 & Primrose \& Ehrlich (1981) \\
pLTV1 & $\mathrm{Cm}$, Tc & $20 \cdot 6$ & 6 & Youngman (1990) \\
\hline
\end{tabular}

* A shuttle plasmid between Bacillus and E. coli, carrying $\mathrm{Km}$ and Ap resistances, prepared by ligating pUB110 and pUC18 plasmids at their single EcoRI sites.

were protoplasted. The protoplasts were harvested by centrifugation (RT, $5 \mathrm{~min}, 6000 \mathrm{~g}$ ) and resuspended in the same volume of P-solution.

PEG-induced transformation. Protoplasts were centrifuged (RT, $5 \mathrm{~min}, 6000 \mathrm{~g}$ ) and resuspended in the same volume of P-solution containing CsCl-purified plasmid DNA (final concentration: $1 \mu \mathrm{g} \mathrm{ml}^{-1}$ ). This was mixed with equal volume of PEG solution. After 3 min exposure to PEG the mixture was diluted 12.5 -fold into ART liquid medium and incubated for $90 \mathrm{~min}$ at $30^{\circ} \mathrm{C}$ with agitation. Then non-inhibitory amounts of appropriate antibiotic were added during the expression period of resistance genes $\left(0 \cdot 1 \mu \mathrm{g} \mathrm{Km}\right.$ or $\left.\mathrm{Cm} \mathrm{ml}^{-1}\right)$, which was $30 \mathrm{~min}$ at $30^{\circ} \mathrm{C}$.

Regeneration of protoplasts. Protoplasts were diluted in ART liquid medium and plated in ART soft-agar overlays on ART agar medium. For direct selection of transformants, selective antibiotic $\left(\mathrm{Km} 5 \mu \mathrm{g} \mathrm{ml}^{-1}\right.$ or $\mathrm{Cm} 20 \mu \mathrm{g} \mathrm{ml}^{-1}$ ) was added to both ART agar media. For colony formation the incubation time at $30{ }^{\circ} \mathrm{C}$ depended on the strain and plasmid used (3-6 d).

Restriction endonuclease digestion and ligation. All of the enzymes were purchased from Amersham and were used according to the manufacturer's specifications. Reaction products were analysed by agarose gel electrophoresis.

\section{RESULTS}

\section{Cell wall regeneration}

In order to develop a simple and efficient protoplast regeneration method for $B$. licheniformis $0.5 \mathrm{M}$ sucrose was used in all media as osmotic stabilizer. Optimal conditions for cell wall regeneration were worked out for $B$. licheniformis 19. The effect of $\mathrm{pH}$ was tested at $\mathrm{pH} 7-10$ in ART media. The protoplasts were prepared (from $4.6 \times$ $10^{7}$ c.f.u. $\mathrm{ml}^{-1}$ ) and the cell walls were regenerated as described in Methods. The results are shown in Fig. 1. For cell wall regeneration, the optimum was $\mathrm{pH} \mathrm{8.4.} \mathrm{The}$ efficiency of protoplast preparation and regeneration was determined at this $\mathrm{pH}$ optimum.

Since $B$. licheniformis cells form long chains during early exponential growth, the number of c.f.u. was only an

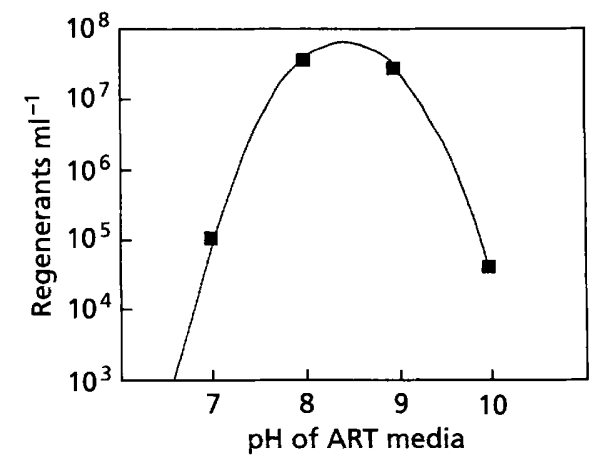

Fig. 1. Influence of pH in ART media on regeneration of cell wall. The data shown are means of three independent

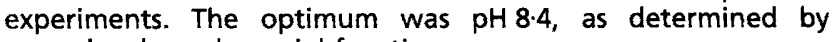
second-order polynomial function. 


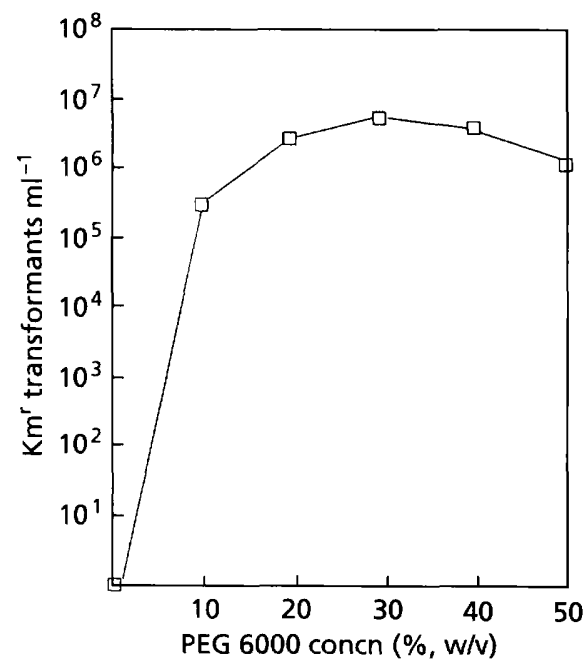

Fig. 2. Effect of PEG concentration on transformation of protoplasts. The data are means of three independent experiments. The optimal PEG final concentration was $30 \%$ $(w / v)$, as determined by second-order polynom, two-sample analysis (performed in pairs) and one-way analysis of variance.

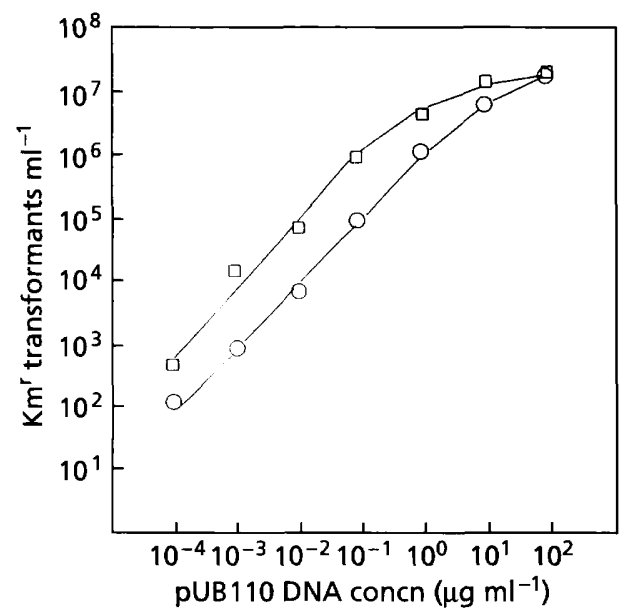

Fig. 3. Effect of plasmid DNA concentration on transformation using pUB110 DNA purified from B. licheniformis $19(\square)$ or $B$. subtilis $27(O)$. The number of regenerants was $2.0 \times 10^{7} \mathrm{ml}^{-1}$. The recipient was $B$. licheniformis 19.

approximate value. Three independent experiments were carried out with B. licheniformis 19 cultures $(4 \cdot 2 \times$ $10^{7}$ c.f.u. $\mathrm{ml}^{-\mathbf{1}}$ ). Protoplasts were prepared as described in Methods. To evaluate the effect of lysozyme treatment, the number of surviving c.f.u. was determined after bursting the protoplasts in sterile distilled water by plating on YTA agar medium: $6.1 \times 10^{3}$ c.f.u. $\mathrm{ml}^{-1}$ were detected and the frequency of osmotic shock resistant cells was around $1.5 \times 10^{-4}$. To determine the efficiency of regeneration the cell wall of protoplasts was restored as described in Methods. The number of regenerants was
$3.5 \times 10^{7} \mathrm{ml}^{-1}$. Regeneration frequencies were on the average $83 \%$, although in some cases we observed $140-180 \%$ regeneration. In these cases more than one protoplast was formed from one bacterial chain.

\section{Conditions for optimum protoplast transformation}

Using the conditions for efficient regeneration described above, the effects of PEG and plasmid DNA concentration on transformation frequencies were studied.

The optimal final concentration of PEG 6000 was determined for B. licheniformis 19 protoplasts using $1 \mu \mathrm{g} \mathrm{ml}^{-1}$ pUB110 DNA (purified from the same strain) in the transformation mixture. Increasing volumes of PEG solution were added to equal volumes of protoplast and plasmid DNA suspensions, so that the final percentages were from 10 to $50(\mathrm{w} / \mathrm{v})$ PEG. Transformants were isolated by direct selection $\left(5 \mu \mathrm{g} \mathrm{Km} \mathrm{m}{ }^{-\mathbf{1}}\right)$. The results are shown in Fig. 2. At the optimal concentration of PEG $(30 \%, \mathrm{w} / \mathrm{v}) 4.1 \times 10^{7}$ regenerated protoplasts $\mathrm{ml}^{-1}$ were detected; $16.6 \%$ of these were transformed.

To study the effect of plasmid DNA concentration on transformation, B. licheniformis 19 protoplasts were transformed with increasing amounts of pUB110 DNA $\left(10^{-4}\right.$ $10^{2} \mu \mathrm{g} \mathrm{ml}^{-1}$ ), purified from B. licheniformis 19 or B. subtilis 27. Transformants were isolated by direct selection on ART agar medium containing $\mathrm{Km}$ (Fig. 3). The $\mathrm{Km}^{\mathrm{r}}$ transformants were transferred to YTA agar medium containing $5 \mu \mathrm{g} \mathrm{Km} \mathrm{ml}^{-1}$, and their plasmid DNA content was detected by the quick-test method. The same plasmid was found in all samples (results not shown). Transformation efficiency depended on the bacterium from which the plasmid DNA was prepared. A significant difference in efficiency was found between DNAs extracted from B. licheniformis 19 and B. subtilis $27\left(4 \cdot 8 \times 10^{6}\right.$ and $1.5 \times 10^{6} \mathrm{Km}^{\mathrm{r}}$ transformants per $\mu \mathrm{g}$ plasmid DNA, respectively: Fig. 3). Transformation frequencies were determined as the ratios (in percentage) of transformants and regenerated protoplasts. The transformation frequencies were $24.0 \%$ and $7.5 \%$ using $1 \mu \mathrm{g} \mathrm{m}{ }^{-1}$ pUB110 purified from B. licheniformis 19 or B. subtilis 27, respectively. Both curves follow a saturation function (Fig. 3). At high DNA concentrations $\left(100 \mu \mathrm{g} \mathrm{m}^{-1}\right)$ all protoplasts became transformed with both donor DNAs.

\section{Transformation of different strains of B. licheniformis}

The transformation efficiencies were compared with four $B$. licheniformis strains in three independent experiments using $1 \mu \mathrm{g} \mathrm{ml}^{-1}$ of pUB110 (Table 3). The numbers of $\mathrm{Km}^{\mathrm{r}}$ transformants were determined and their plasmid content was tested as described before. The transformation efficiency of strain ATCC 9800 was significantly lower than that of strains ATCC 10716 UM12, 19, and 16, as determined by two-sample analysis $(95 \%$ significance level). There were also differences among the strains with respect to the time required for cell wall regeneration. This time was shorter for B. licheniformis 16 or 19 , and longer for ATCC 9800. 
Table 3. Transformation frequencies of $B$. licheniformis strains by pUB110

pUB110 DNA was purified from B. subtilis 27. Values are means of three independent experiments.

\begin{tabular}{|lccc|}
\hline Strain & $\begin{array}{c}\text { No. of transformants } \\
(\mu \mathrm{g} \mathrm{DNA})^{-1}\end{array}$ & $\begin{array}{c}\text { Transformation } \\
\text { frequency (\%) }\end{array}$ & $\begin{array}{c}\text { Incubation } \\
\text { time (d) }\end{array}$ \\
\hline ATCC 9800 & $3.5 \times 10^{5}$ & $1 \cdot 8$ & $5-6$ \\
ATCC 10716 UM12 & $1 \cdot 1 \times 10^{6}$ & $6 \cdot 1$ & 5 \\
19 & $1 \cdot 3 \times 10^{6}$ & $5 \cdot 9$ & $3-4$ \\
16 & $1 \cdot 5 \times 10^{6}$ & $5 \cdot 8$ & $3-4$ \\
\hline
\end{tabular}

Table 4. Transformation frequency of $B$. licheniformis 19

\begin{tabular}{|lccc|}
\hline Plasmid & $\begin{array}{c}\text { Selected } \\
\text { marker }\end{array}$ & $\begin{array}{c}\text { No. of } \\
\text { transformants } \\
(\boldsymbol{\mu g} \text { DNA })^{-1}\end{array}$ & $\begin{array}{c}\text { Transformation } \\
\text { frequency* } \\
\text { (\%) }\end{array}$ \\
\hline pUBUC18 & $\mathrm{Km}^{\mathrm{r}}$ & $7 \cdot 2 \times 10^{6}$ & $25 \cdot 7$ \\
pUB110 & $\mathrm{Km}^{\mathrm{r}}$ & $5 \cdot 8 \times 10^{6}$ & $20 \cdot 7$ \\
pAT187 & $\mathrm{Km}^{\mathrm{r}}$ & $3 \cdot 3 \times 10^{6}$ & $11 \cdot 8$ \\
pHV33 & $\mathrm{Cm}^{\mathrm{r}}$ & $1.8 \times 10^{6}$ & $6 \cdot 4$ \\
pLTV1 & $\mathrm{Cm}^{\mathrm{r}}$ & $1.3 \times 10^{6}$ & $4 \cdot 6$ \\
\hline
\end{tabular}

*The number of regenerated protoplasts was $2 \cdot 8 \times 10^{7} \mathrm{ml}^{-1}$.

Table 5. Transformation with cut and ligated pUBUC18 DNA

pUBUC18 (Table 2) contains a unique HindIII site which originated on pUC18, and two EcoRI sites where pUB110 $(4.548 \mathrm{~kb})$ and $\mathrm{pUC1}(2.686 \mathrm{~kb})$ are joined. Restriction endonuclease digestions and ligation with T4 DNA ligase were performed as described in Methods. The recipient was $B$. licheniformis 19.

\begin{tabular}{|lc|}
\hline Plasmid DNA & $\begin{array}{c}\text { No. of transformants } \\
(\mu \mathrm{g} \text { DNA })^{-1}\end{array}$ \\
\hline Untreated & $6.4 \times 10^{6}$ \\
EcoRI treated & $4.5 \times 10^{3}$ \\
EcoRI + T4 ligase & $1.9 \times 10^{6}$ \\
HindIII treated & $2.7 \times 10^{4}$ \\
HindIII + T4 ligase & $8.1 \times 10^{5}$ \\
\hline
\end{tabular}

\section{Protoplast transformation by different plasmids}

Five plasmids of different size and copy number, carrying $\mathrm{Km}$ or $\mathrm{Cm}$ resistances, were introduced into the protoplasts of B. licbeniformis 19 . We used $1 \mu \mathrm{g} \mathrm{m}^{-1}$ plasmid DNAs (from B. licheniformis 19) and transformants were isolated by direct selection (Table 4). Transformants and their plasmid contents were tested as described in foregoing sections. The size and the EcoRI or Bam HI restriction endonuclease digestion patterns of the plas- mids were the same in the transformants as in the original strain, suggesting that the plasmids were maintained in $B$. licheniformis without any deletions or rearrangements. The transformation frequencies were compared by two-sample analysis, and the results were the following. There was no significant difference between pUB110 and pUBUC18, which are based on the same replicon, though their sizes are different. Likewise, no significant difference in transformation efficiency was found between various lowcopy-number plasmids of different size (pLTV1 is nearly three times bigger than pHV33). Significant differences were found, however, between the high-copy-number plasmids (pUBUC18, pUB110) and the low-copy-number plasmids (pAT187, pHV33, pLTV1). $\mathrm{Cm}^{\mathrm{r}}$ transformants formed colonies $2-3 \mathrm{~d}$ later than $\mathrm{Km}^{\mathrm{r}}$ transformants.

\section{Protoplast transformation by cut and ligated plasmid DNA}

The transformation efficiencies of restriction endonuclease digested and ligated plasmid DNA were determined for B. licheniformis 19 protoplasts using $1 \mu \mathrm{g} \mathrm{ml}^{-1}$ uncut, EcoRI treated, HindIII treated and ligated pUBUC18 DNAs in the transformation mixtures (Table 5). Transformants were selected on ART agar medium containing $\mathrm{Km}\left(5 \mu \mathrm{g} \mathrm{ml}^{-1}\right)$. The numbers of transformants were determined and their plasmid content was tested as described above. In the case of EcoRI digested and T4 DNA ligase treated plasmid DNA, $16 \%$ of the tested $\mathrm{Km}^{\mathrm{r}}$ colonies (231) contained pUBUC18 ('recombinant DNA'), and $84 \%$ contained pUB110.

\section{DISCUSSION}

The most limiting step in the transformation of $B$. licheniformis protoplasts seems to be the regeneration of the cell wall, because the L-form colonies arising from protoplasts appear unable to revert to normal cells (Bourne \& Dancer, 1986; Jensen \& Hulett, 1989). Regenerants have been obtained by several investigators, for instance when succinate in the regeneration medium was replaced by mannitol (Wati et al., 1990), or gelatin was added to this medium (Bourne \& Dancer, 1986), or when the incubation temperature was increased to $46^{\circ} \mathrm{C}$ (Jensen \& Hulett, 1989), or when the growth and regeneration media were different (Bron, 1990). The frequencies of 
regeneration described so far in the literature are low, in the range of $6 \times 10^{-2}-1 \times 10^{-3}$ per protoplasted cell (Bourne \& Dancer, 1986; Jensen \& Hulett, 1989). The procedures described up to now were only suitable for a few B. licheniformis strains and were poorly reproducible (Jensen \& Hulett, 1989; Wati et al., 1990). The method described in the present work is simpler and the frequency of regeneration $(83 \%)$ was almost as high as that reported by Gabor \& Hotchkiss (1979) for B. subtilis protoplasts. Efficient regeneration was achieved without using special protoplast stabilizing agents such as gelatin or bovine serum albumin. Osmotic protection was obtained with $0.5 \mathrm{M}$ sucrose and salts (i.e. $\mathrm{NH}_{4}^{+}, \mathrm{K}^{+}, \mathrm{Na}^{+}$, $\mathrm{Mg}^{2+}$ ), as in earlier studies with $B$. licheniformis protoplasts (Snoke \& Cornell, 1965).

The maximum number of transformants was obtained using $30 \%$ (w/v) PEG 6000 for DNA uptake, although there were no big differences in the range from $20 \%$ to 40\% PEG (Fig. 2).

There was a linear relationship between transformation frequency and DNA concentration in the range $10^{-4}$ to $1 \mu \mathrm{g} \mathrm{DNA} \mathrm{ml}{ }^{-1}$ (Fig. 3), where $1 \mathrm{Km}^{\mathrm{r}}$ transformant was detected per $1-3 \times 10^{4}$ molecules of pUB110 (from $B$. licheniformis 19). These efficiencies are three to five orders of magnitude higher than those obtained by Jensen \& Hulett (1989), Wati et al. (1990), and Bron (1990) for B. licheniformis, and were nearly the same as those observed by Chang \& Cohen (1979) for B. subtilis.

The MIC of $\mathrm{Km}$ was increased in the succinate-based regeneration medium from 5 to $100 \mu \mathrm{g} \mathrm{ml}^{-1}$ for $B$. subtilis (Chang \& Cohen, 1979) and from 20 to $300 \mu \mathrm{g} \mathrm{ml}^{-1}$ for B. licheniformis (Grosch \& Wollweber, 1982), and Jensen \& Hulett (1989) found that concentrations of $\mathrm{Km}$ up to $2 \mathrm{mg} \mathrm{ml}^{-1}$ were ineffective in the direct selection of $\mathrm{Km}^{\mathrm{r}}$ transformants. Since ART media do not contain any succinate, direct selection could be performed with $5 \mu \mathrm{g}$ $\mathrm{Km} \mathrm{ml}^{-1}$ in our experiments.

Significant differences were found between the transformation efficiencies in $B$. licheniformis 19 with the same plasmid isolated from $B$. subtilis or from B. licheniformis (Fig. 3). This may indicate that different restrictionmodification systems exist in the two species. If this idea is correct, it appears that the plasmid DNA extracted from $B$. subtilis is inappropriately modified for B. licheniformis.

Efficient transformation of four B. licheniformis strains was achieved with pUB110 DNA (from $B$. subtilis 27) (Table $3)$. Significant differences were found among the transformation frequencies of the strains, and yields were $3.5 \times 10^{5}-1.5 \times 10^{6}$ transformants per $\mu \mathrm{g}$ plasmid DNA, depending on the strain.

Comparing five different plasmids (Table 4), a negative correlation was not noticed between transformation frequency and plasmid size, but significant differences were found between high- (pUBUC18, pUB110) and lowcopy-number plasmids (pAT187, pHV33, pLTV1), as Zhang et al. (1988) reported for B. stearotbermopbilus.

Endonuclease digested and ligated plasmid DNA could be introduced at high efficiency into $B$. licheniformis protoplasts by this transformation system (Table 5), although the frequencies were half to three orders of magnitude lower than that for uncut plasmid DNA, as observed by Chang \& Cohen (1979) for B. subtilis. Without any selection for insert DNA, a high proportion $(16 \%)$ of the transformants carried recombinant DNA. These results demonstrate that the transformation procedure described here seems to be a useful tool for cloning in B. licheniformis.

\section{ACKNOWLEDGEMENTS}

We are grateful to È. Balla, T. Imanaka, F. G. Priest and È. Vincze for the generous gifts of plasmids and strains. We would like to thank Petra Kiss, Son Lam Phan Tran and Lóránd Szabó for carrying out some of the tests.

\section{REFERENCES}

Bourne, N. \& Dancer, B. N. (1986). Regeneration of protoplasts of Bacillus subtilis 168 and closely related strains. J Gen Microbiol 132, 251-255.

Bron, S. (1990). Plasmids. In Molecular Biological Methods for Bacillus, pp. 75-174. Edited by C. R. Harwood \& S. M. Cutting. Chichester: John Wiley.

Chang, S. \& Cohen, S. N. (1979). High frequency transformation of Bacillus subtilis protoplasts by plasmid DNA. Mol \& Gen Genet 168, 111-115.

Fodor, K., Hadlaczky, G. \& Alföldi, L. (1975). Reversion of Bacillus megaterium protoplasts to the bacillary form. J Bacteriol 121, 390-391.

Gabor, M. H. \& Hotchkiss, R. D. (1979). Parameters governing bacterial regeneration and genetic recombination after fusion of Bacillus subtilis protoplasts. J Bacteriol 137, 1346-1353.

Grosch, J. C. \& Wollweber, K. L. (1982). Transformation of Bacillus licheniformis and Bacillus amyloliquefaciens protoplasts by plasmid DNA. In Genetic Exchange, pp. 97-105. Edited by U. N. Streips, S. H. Goodgal, W. R. Guild \& G. A. Wilson. New York: Marcel Dekker.

Harwood, C. R. (1992). Bacillus subtilis and its relatives: molecular biological and industrial workhorses. TIBTECH 10, 247-256.

Jensen, K. K. \& Hulett, F. M. (1989). Protoplast transformation of Bacillus licbeniformis MC14. J Gen Microbiol 135, 2283-2287.

Kieser, T. (1984). Factors affecting the isolation of CCC DNA from Streptomyces lividans and Escherichia coli. Plasmid 12, 19-36.

Kleinkauf, H. \& von Döhren, H. (1987). Biosynthesis of peptide antibiotics. Annu Rev Microbiol 41, 259-289.

Primrose, S. B. \& Ehrlich, S. D. (1981). Isolation of plasmid deletion mutants and study of their instability. Plasmid 6, 193-201.

Sík, T., Horváth, J. \& Chatterjee, S. (1980). Generalized transduction in Rbizobium meliloti. Mol \& Gen Genet 178, 511-516.

Snoke, J. E. \& Cornell, N. (1965). Protoplast lysis and inhibition of growth of Bacillus licheniformis by bacitracin. J Bacteriol 89, 415-420.

Sueoka, N., Hoshino, T., McKenzie, T. \& Sonis, D. (1986). Membrane binding and regulation of replication initiation of pUB110 in Bacillus subtilis. In Bacillus Molecular Genetics and Biotechnology Applications, pp. 47-54. Edited by A. T. Ganesan \& J. A. Hoch. Orlando: Academic Press.

Trieu-Cuot, P., Carlier, C., Martin, P. \& Courvalin, P. (1987). Plasmid transfer by conjugation from Escherichia coli to Grampositive bacteria. FEMS Microbiol Lett 48, 289-294. 
Wati, M. R., Priest, F. G. \& Mitchell, W. J. (1990). Mutagenesis using Tn917 in Bacillus licheniformis. FEMS Microbiol Lett 71, 211-214.

Youngman, P. (1990). Use of transposons and integrational vectors for mutagenesis and construction of gene fusions in Bacillus species. In Molecular Biological Methods for Bacillus, pp. 221-266. Edited by C. R. Harwood \& S. M. Cutting. Chichester: John Wiley.
Zhang, M., Nakai, H. \& Imanaka, T. (1988). Useful host-vector systems in Bacillus stearothermophilus. Appl Environ Microbiol 54, $3162-3164$.

Received 11 June 1993; revised 20 August 1993; accepted 2 September 1993. 